\title{
ANALISIS PENGARUH DESENTRALISASI FISKAL, INVESTASI DAN PENDUDUK TERHADAP PRODUK DOMESTIK REGIONAL BRUTO, KAPASITAS FISKAL DAN PENGELUARAN PEMERINTAH DAERAH DI PROVINSI PAPUA
}

\author{
ABSTRACT \\ Dewi Adhityarani Musaidah' \\ d_adhityarani@yahoo.com \\ Ida Ayu Purba Riani \\ purbariani@gmail.com \\ Elsyan R. Marlissa ${ }^{3}$ \\ elsyan_marlissa@yahoo.com
}

This study aims to answer how the influence of fiscal capacity, regional government spending, investment and the residents to regional gross domestic product (GDP) and fiscal capacity of regional government spending. There are seven exogenous variables, three endogenous variables analyzed use the Two Stage Least Square (2SLS), that produces simultaneous estimation equation model. The result showed fiscal capacity, regional government spending, foreign investment, domestic investment, and residents simultaneously significant to the regional GDP. The second model, the fiscal capacity of regional GDP, local taxes, and levies, simultaneously significant to fiscal capacity. The third model, regional government spending show the regional GDP, fiscal capacity, local revenue, balance funds, and residents simultaneously will not affect local government spending.

Keywords: Fiscal decentralization, investment, Residents, regional gross domestic product, fiscal capacity, provinces of papua government spending.

\section{PENDAHULUAN}

Menurut Sekda Provinsi Papua, (Hery Dosinaen 2017) menyatakan bawa pendapatan daerah mencapai Rp.13,9 triliun, berdasarkan total pendapatan daerah tersebut, Pendapatan Asli Daerah hanya berkontribusi 7,23 persen, sedangkan Dana Perimbangan sebesar 24,8 persen serta lainnya dari lain-lain pendapatan yang sah paling tinggi sekitar 67,9 persen.

\footnotetext{
${ }^{1}$ Alumni Mahasiswa Magister Keuangan Daerah Universitas Cenderawasih

${ }^{2}$ Staf Dosen Jurusan IImu Ekonomi Fakultas Ekonomi \& Bisnis Universitas Cenderawasih

${ }^{3}$ Staf Dosen Jurusan IImu Ekonomi Fakultas Ekonomi \& Bisnis Universitas Cenderawasih
} 
Ditinjau dari Belanja daerah ternyata total belanja daerah Provinsi Papua terjadi defisit anggaran sebesar Rp. 1,5 triliun di Provinsi Papua, karena begitu tingginya kebutuhan pembangunan sedangkan kapasitas fiskal daerah tidak begitu cukup. Dengan demikian dikatakan bahwa, Pendapatan Asli Daerah masih memberikan dampak kecil terhadap belanja daerah melalui program dan kegiatan di Provinsi Papua.

Peningkatan provinsi Papua dapat terwujud dari kapasitas fiskal yang besar. Kemandirian provinsi suatu daerah dapat dilihat dari kapasitas fiskal yang dimiliki daerah tersebut, semakin besar kontribusi kapasitas fiskal terhadap penerimaan daerah maka semakin tinggi kemampuan daerah dalam membiayai semua kebutuhan daerah.

Akan tetapi jika persentase kapasitasnya relatif kecil, daerah tersebut sangat tergantung kepada dana berimbang (Dana Alokasi Umum, Dana Alokasi Khusus dan Dana Bagi hasil), artinya pemerintah daerah mengalami ketergantungan yang sangat tinggi terhadap dana yang diberikan oleh pusat. Oleh sebab itu, perlu adanya inventarisasi potensi yang ada, di mana potensi daerah akan dijadikan sebagai sumber penerimaan. Begitu pun yang seharusnya terjadi dalam skema kapasitas fiskal di provinsi Papua.

Pembangunan daerah bertumpuh pada (UU Nomor 22 Tahun 1999) yang secara umum menjelaskan pembangunan daerah dilaksanakan melalui penguatan otonomi daerah dan pengeloloaan sumber daya yang bermuara pada tata kelola pemerintahan yang baik. Dalam kaitan itu, otonomi daerah juga memberi hak dan wewenang kepada daerah untuk mengatur dan mengurus sendiri urusan pemerintahan dan kepentingan warga setempat sesuai amanat undang-undang.

Menurut (UU Nomor 32 Tahun 2004) tentang Pemerintahan Daerah Pasal 1 ayat 5. "Otonomi daerah adalah hak, wewenang, dan kewajiban daerah otonom untuk mengatur dan mengurus sendiri urusan pemerintahan dan kepentingan masyarakat setempat sesuai dengan peraturan perundang-undangan". Dari pengertian tersebut dapat diartikan bahwa 
ANALISIS PENGARUH DESENTRALISASI FISKAL, INVESTASI DAN PENDUDUK TERHADAP PRODUK DOMESTIK REGIONAL BRUTO, KAPASITAS FISKAL DAN PENGELUARAN PEMERINTAH DAERAH DI PROVINSI PAPUA

otonomi daerah merupakan kemerdekaan atau kebebasan menentukan aturan sendiri berdasarkan perundang-undangan, dalam memenuhi kebutuhan daerah sesuai dengan potensi dan kemampuan yang dimiliki oleh daerah.

Otonomi daerah yang sudah berjalan diharapkan bukan hanya pelimpahan wewenang dari pusat kepada daerah untuk menggeser kekuasaan. Hal ini ditegaskan oleh Kaloh (2002), bahwa otonomi daerah harus didefinisikan sebagai otonomi bagi rakyat daerah bukan otonomi "daerah" dalam pengertian wilayah/teritorial tertentu di tingkat lokal.

Otonomi daerah bukan hanya merupakan pelimpahan wewenang tetapi juga peningkatan partisipasi masyarakat dalam pembangunan daerah. Adapun dasar hukum pelaksanaan otonomi daerah adalah : (1) Undang-undang Dasar Tahun 1945 Amandemen ke-2 yang terdiri dari : Pasal 18 Ayat $1-7$, Pasal 18A Ayat 1 dan 2, dan Pasal 18B ayat 1 dan 2; (2) Ketetapan MPR RI Nomor XV/MPR/1998 tentang Penyelenggaraan Otonomi Daerah; (3) Ketetapan MPR RI Nomor IV/MPR/2000 mengenai Rekomendasi Kebijakan dalam Penyelenggaraan Otonomi Daerah; (4) Undang Undang No. 32 Tahun 2004 mengenai Pemerintahan Daerah dan (5) Undang Undang No. 33 Tahun 2004 tentang Perimbangan Keuangan antara Pemerintah Daerah dan Pusat.

Konsep dan Desentralisasi Fiskal. Penerapan otonomi daerah/ desentralisasi yang luas diharapkan mampu mengatasi permasalahan pada masa orde baru. Pengertian desentralisasi adalah pelimpahan wewenang dari pusat kepada daerah. Desentralisasi merupakan sebuah alat untuk mencapai salah satu tujuan bernegara, khususnya dalam rangka memberikan pelayanan umum yang lebih baik dan menciptakan proses pengambilan keputusan umum yang lebih demokratis.

Desentralisasi fiskal merupakan salah satu komponen utama dari desentralisasi (Sidik 2002). Desentralisasi fiskal secara resmi berlaku mulai 1 Januari 2001 berdasarkan UU RI No. 25 tahun 1999 yang disempurnakan dengan (UU RI No. 33 tahun 2004). Desentralisasi fiskal merupakan 
pelimpahan wewenang kepada daerah dalam mengelola sumber - sumber keuangan sendiri, sehingga daerah mempunyai kesempatan yang lebih dalam mengatur rumah tangganya.

Desentralisasi Fiskal diartikan sebagai pelimpahan wewenang di bidang penerimaan anggaran atau keuangan yang sebelumnya tersentralisasi, baik secara administrasi maupun pemanfaatannya diatur atau dilakukan oleh pemerintah pusat. Dengan terjadinya pelimpahan sebagian wewenang terhadap sumber -sumber penerimaan di daerah, diharapkan daerah-daerah dapat melaksanakan tugas-tugas rutin, pelayanan publik dan meningkatkan investasi yang produktif (capital investment) di daerahnya (Ladjin 2008).

Secara garis besar investasi merupakan pengeluaran pemerintah untuk membelanjakan barang-barang modal atau peralatan penunjan yang akan digunakan untuk memproduksi barang dan jasa dimasa yang akan datang. Sementara bila dilihat dari berbagai sumber tentang investasi pada umumnya menjelaskan investasi merupakan satu komponen yang terkait langsung dengan $\mathrm{PDB}=\mathrm{C}+\mathrm{I}+\mathrm{G}(\mathrm{X}-\mathrm{M})$.

Sejalan dengan itu, Samuelson 2004), secara umum menjelaskan investasi meliputi penambahan barang di suatu wilayah, seperti property atau peralatan produksi atau langkah mengorbankan konsumsi di waktu mendatang.

Selanjutnya pentingnya tabungan berdasarkan teori neo klasik menjelaskan tabungan sebagai umber investasi. Pada teori neo klasik juga menjelaskan bahwa investasi biasa dipandang sebagai salah satu pengerak utama pertumbuhan ekonomi dan pembagunan.

Menurut (Siska Permata Indah 2011), Penelitian dengan judul Analisis dampak desentralisasi fiskal dan pengaruhnya terhadap PDRB, Tenaga Kerja, dan Kemiskinan di Provinsi Jawa Barat. Menggunakan metode analisis deskriptif dan simultan (2SLS). Hasil dari penelitian kebijakan desentralisasi fiskal berpengaruh positif terhadap PDRB Jawa Barat tetapi tidak signifikan terhadap tenaga kerja. 
Faktor-faktor yang signifikan meningkatkan PDRB Jawa Barat adalah PAD, dana transfer, investasi, ekspor dan impor, tenaga kerja, dummy desentralisasi fiskal. Sedangkan variabel dummy krisis ekonomi berpengaruh negatif terhadap PDRB Jawa Barat. Kebijakan desentralisasi fiskal belum mampu menjamin ketersediaan lapangan kerja (pro job) sehingga tidak dapat menekan angka pengangguran di Jawa Barat. Peningkatan PDRB signifikan mengurangi jumlah penduduk miskin.

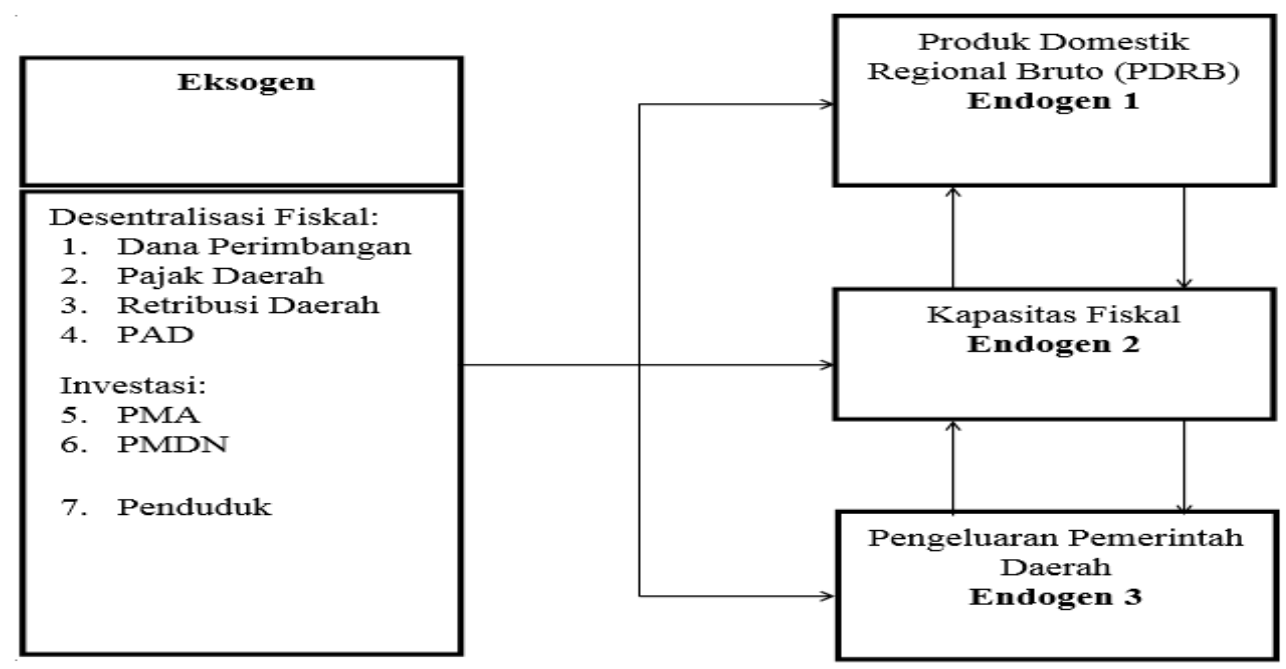

\section{Gambar 1 Kerangka Pemikiran}

Sumber : berbagai sumber, 2018

Kebijakan desentralisasi Indonesia telah secara mendasar mengubah sistem pemerintahan di Indonesi melalui pelakasanaan UU seperti UU No. 22 tahun 1999 tentang Pemerintah Daerah dan UU No 25. Tahun 1999 tentang Keseimbangan Fiskal antara Pemerintah Daerah dan Pemerintah Pusat. Sejak itu, kedua UU ini digantikan oleh UU No. 32 tahun 2004 dan UU No. 33 tahun 2004 yang memberikan ketetapan yang lebih jelas dan rinci untuk pelaksanaan desentralisasi dan otonomi daerah.

Undang-Undang ini menegaskan komitmen Indonesia untuk mengembangkan otonomi daerah sebagai suatu cara untuk meningkatkan penyediaan pelayanan, kesejahteraan masyarakat dan menjamin stabilitas 
ANALISIS PENGARUH DESENTRALISASI FISKAL, INVESTASI DAN PENDUDUK TERHADAP PRODUK DOMESTIK REGIONAL BRUTO, KAPASITAS FISKAL DAN PENGELUARAN PEMERINTAH DAERAH DI PROVINSI PAPUA

politik, ekonomi dan sosial bangsa. Pemerintah telah melakukan berbagai upaya untuk memfasilitasi kelancaran pelaksanaan UU yang telah ditetapkan.

Pertumbuhan ekonomi provinsi Papua triwulan II tahun 2017 tercatat mengalami peningkatan lebih tinggi dibanding triwulan sebelumnya. Sebagaimana dikutip dalam kajian ekonomi dan keuangan regional provinsi Papua Agustus 2017, kinerja perekonomian provinsi Papua mencapai $4,91 \%$ (yoy) pada triwulan II lebih tinggi dibandingakan kinerja triwulan sebelumnya hanya sebesar 3,36\% (yoy). Terlihat dari perbaikan performa ekspor ke luar negeri dari provinsi Papua menjadi penopang tingginya pertumbuhan pada triwulan II. Dari sisi lapangan usaha peningkatan penjualan konsentrat mineral hasil tambang menjadi faktor dominan yang mempengaruhi pertumbuhan ekonomi.

Pertumbuhan ekonomi suatu daerah dipengaruhi oleh desentralisasi fiskal, begitupun pertumbuhan ekonomi provinsi Papua. Keberhasilan desentralisasi fiskal provinsi Papua bisa didukung dengan pendapatan asli daerah (PAD) yang besar, penanaman modal yang memadai, pajak daerah, dana berimbang, pemasukan retribusi dan penududk yang sejahtera (Juwani 2007). Semakin tinggi pendapatan daerah provinsi maka semakin pembangunan yang dilakukan oleh provinsi Papua.

Adapun instrumen desentralisasi fiskal yaitu dana perimbangan, pajak daerah, retribusi daerah dan $P A D$, instrument dari investasi yaitu PMA dan PMDN. Berdasarkan beberapa teori dan penelitian terdahulu peneliti merujuk pada buku Direktorat Jendral Perimbangan Keuangan Kementrian Keuangan (2011) dan dari penelitian (Zhang dan Zhou 1998), (Annisa Irdhania 2009), dan (Ahmad Dorani 2008).

H1: Diduga hahwa kapasitas fiskal, pengeluaran pemerintah daerah, PMA, PMDN dan penduduk berpengaruh signifikan terhadap Produk Domestik Regional Bruto. 
H2: Diduga hahwa Produk Domestik Regional Bruto, Pajak Daerah, dan retribusi daerah berpengaruh signifikan terhadap kapasitas fiskal.

H3: Diduga bahwa Produk Domestik Regional Bruto, kapasitas fiskal, Pendapatan asli daerah, Dana Perimbangan dan penduduk berpengaruh signifikan terhadap pengeluaran pemerintah daerah.

\section{METODE PENELITIAN}

Tehnik analisis dalam penelitian ini menggunakan deskriptif kuantitatif dan analsisi statistik dengan sumber data sekunder seperti Data Dalam Angka (DDA), Produk Domestik Regional Bruto (PDRB), Kependudukan, Pendapatan perkapita bersumber dari Badan Pusat Statistik Provinsi Papua, Fiskal Keuangan Daerah bersumber dari DJPK RI, Realisasi PMDN bersumber dari Bank Indonesia dan berbagai literature, referensi, jurnal. Sementara analisis Two Stage Least Square (2SLS) ini digunakan untuk mendapatkan hasil yang optimal.

Persamaan Simultan. Simultan adalah situasi dimana adanya hubungan dua arah antara variabel independent dan variabel dependent. Variabel $Y$ tidak hanya ditentukan oleh $X$ karena beberapa dari variabel $X$ juga ditentukan oleh Y. Terdapat beberapa persamaan dalam model ini dan masing-masing variabel dependent bersifat endogen (Gujarati 1978).

$$
Y_{1 \mathrm{t}}=\beta_{12} Y_{2 \mathrm{t}}+\beta_{13} Y_{3 \mathrm{t}}+\ldots+\beta_{1 \mathrm{M}} Y_{M t}+\mathrm{Y}_{11} X_{1 \mathrm{t}}+\ldots+\mathrm{Y}_{1 \mathrm{~K}} \mathrm{X}_{\mathrm{kt}}+\mu_{1 \mathrm{t}}
$$

Dengan :

$\mathrm{Y}_{1}, \mathrm{Y}_{2, \ldots,}, \mathrm{Y}_{\mathrm{M}} \quad: \mathrm{M}$ variabel endogen, atau variabel tak bebas bersama

$\mathrm{X}_{1}, \mathrm{X}_{2, \ldots,} \mathrm{X}_{\mathrm{K}} \quad \mathrm{K}$ variabel yang ditetapkan terlebih dahulu

$\mu_{1}, \mu_{1, \ldots,}, \mu_{M} \quad: M$ gangguan stokastik

$\mathrm{t}=1,2, \ldots, \mathrm{N}$ : banyak observasi total

$\beta \quad$ : koefisien variabel endogen

Spesifikasi Model. Spesifikasi model merupakan tahap awal untuk menentukan bentuk model persamaan yang akan diestimasi parameternya.

$\mathrm{Yt}=\beta_{10}+\beta_{11} \mathrm{CPFt}+\beta_{12}$ TEXPt $+\gamma_{11} \mathrm{PMAt}+\gamma_{12} \mathrm{PMDNt}+\gamma_{13} \mathrm{PENDt}+\mu_{1 \mathrm{t}}$

CPFt $=\beta_{20}+\beta_{21} Y t+\beta_{22} R T A X t+\gamma_{21} R R E T t+\mu_{2 t}$

$T E X P t=\beta_{30}+\beta_{31} Y t+\beta_{32} C P F t+\gamma_{31} P A D t+\gamma_{32} D P t+\gamma_{33} P E N D t+\mu_{3 t}$ 
Keterangan variabel dalam model :

$$
\begin{array}{cl}
\mathrm{Y}_{\mathrm{t}} & : \text { Produk Domestik Regional Bruto } \\
\text { TEXP }_{\mathrm{t}} & : \text { Pengeluaran Pemerintah Daerah } \\
\mathrm{CPF}_{\mathrm{t}} & : \text { Kapasitas Fiskal } \\
\mathrm{PMA}_{\mathrm{t}} & : \text { Penanaman Modal Asing } \\
\text { PMDN }_{\mathrm{t}} & : \text { Penanaman Modal Dalam Negeri } \\
\text { PEND }_{\mathrm{t}} & : \text { Penduduk } \\
\mathrm{RTAX}_{\mathrm{t}} & : \text { Pajak Daerah } \\
\text {RRET}_{\mathrm{t}} & : \text { Retribusi Daerah } \\
\text { PAD }_{\mathrm{t}} & : \text { Pendapatan Asli Daerah } \\
\mathrm{DP}_{\mathrm{t}} & : \text { Dana Perimbangan }
\end{array}
$$

Identifikasi Model. Dalam melakukan pendugaan parameter, suatu persamaan di dalam model simultan harus teridentifikasi. Kondisi yang harus dipenuhi agar suatu model dapat diidentifikasi adalah :

$$
\mathrm{K}-\mathrm{M} \geq \mathrm{G}-1
$$

Dimana :

$\mathrm{K}=$ Total variabel dalam model (variabel endogen dan variabel predeterminan)

$\mathrm{M}$ = Jumlah variabel endogen dan eksogen yang dimasukkan dalam suatu persamaan tertentu dalam model

$\mathrm{G}=$ Total persamaan

Apabila K-M sama dengan G-1 maka suatu persamaan di dalam model dikatakan teridentifikasi secara tepat (exactly Identified); jika K-M lebih kecil dari G-1, maka persamaan dikatakan tidak teridentifikasi (underidentified); sedangkan jika K-M lebih besar dari G-1 maka persamaan tersebut dikatakan teridentifikasi berlebih (overidentified).

Apabila suatu persamaan simultan dalam kondisi exactly identified, maka metode pendugaan yang tepat digunakan adalah Indirect Least Square (ILS). Apabila suatu persamaan simultan dalam kondisi overidentified, maka metode pendugaan yang tepat digunakan adalah Two 
Stage Least Square (2SLS). Sedangkan jika persamaan simultan tidak teridentifikasi maka tidak dapat diduga.

Masalah identifikasi model ini dilakukan dengan tujuan untuk mengetahui apakah estimasi parameter dapat dilakukan melalui persamaan reduced form dari sistem persamaan simultan sehingga dapat ditentukan metode yang sesuai. Berikut disajikan hasil identifikasi model sebagai berikut:

Yt $\quad=\beta_{10}+\beta_{11} C P F t+\beta_{12}$ TEXPt $+\gamma_{11}$ PMAt $+\gamma_{12}$ PMDNt $+\gamma_{13} P E N D t+\mu_{1 t}$

(Model 1)

$\mathrm{CPFt}=\beta_{20}+\beta_{21} \mathrm{Yt}+\beta_{22} \mathrm{RTAXt}+\mathrm{\gamma}_{21} \mathrm{RRETt}+\mu_{2 t}$

(Model 2)

$T E X P t=\beta_{30}+\beta_{31} Y t+\beta_{32} C P F t+\gamma_{31} P A D t+\gamma_{32} D P t+\gamma_{33} P E N D t+\mu_{3 t}$

(Model 3)

Berdasarkan ke 3 model di atas diperloleh nilai $\mathrm{K}$, $\mathrm{k}$, dan $\mathrm{m}$ sebagai berikut:

K $: 16$

M : Model $1=6$, Model $2=4$, dan Model $3=6$

G $\quad$ : Model $1=5$, Model $2=3$, dan Model $3=5$

Tabel 1 Identifikasi Model

\begin{tabular}{|c|c|c|c|}
\hline Model & K-M & G-1 & $\begin{array}{c}\text { Identifikasi } \\
\text { Model }\end{array}$ \\
\hline Model 1 & 10 & 4 & Overidentified \\
\hline Model 2 & 12 & 2 & Overidentified \\
\hline Model 3 & 10 & 4 & Overidentified \\
\hline
\end{tabular}

Berdasarkan tabel di atas dapat di ketahui bahwa seluruh model dalam penelitian termasuk dalam kategori overidentified, sehingga parameter-parameter dalam persamaan mempunyai lebih dari satu hasil estimasi yang bisa digunakan dan dapat di estimasi menggunakan Two Stage Least Square. 
ANALISIS PENGARUH DESENTRALISASI FISKAL, INVESTASI DAN PENDUDUK TERHADAP PRODUK DOMESTIK REGIONAL BRUTO, KAPASITAS FISKAL DAN PENGELUARAN PEMERINTAH DAERAH DI

PROVINSI PAPUA

\section{HASIL DAN PEMBAHASAN}

Analisis Two Stage Least Square (2sls). Two Stage Least Square (2SLS) adalah salah satu metode regresi yang termasuk ke dalam kelompok analisis persamaan struktural. Metode ini merupakan perluasan dari metode OLS yang biasa digunakan dalam perhitungan analisis regresi. 2SLS digunakan dalam kondisi dimana terdapat korelasi antara error yang dihasilkan dalam model berkorelasi dengan variabel bebasnya.

Mengapa disebut Two Stage Least Square, karena terdapat two stage atau dua langkah dan pada dasarnya hanya merupakan perluasan dari metode OLS (Ordinary Least Square). Berikut disajikan hasil estimasi berdasarkan persamaan produk domestik regional bruto, kapasitas fiskal, dan pengeluaran pemerintah daerah dengan hasil sebagai berikut.

Hasil Estimasi Produk Domestik Regional Bruto. Hasil estimasi model persamaan simultan terhadap produk domestik regional bruto menunjukkan bahwa model yang dibangun signifikan pada taraf nyata 5 persen dan mampu menjelaskan permasalahan dengan sangat baik. Hal ini terlihat dari nilai $R$-squared nya yaitu sebesar 0,9992 yang berarti bahwa model telah mampu menjelaskan keragaman masalah sebesar 99,92 persen dan sisanya sebesar 0,08 persen dijelaskan oleh variabel-variabel di luar model (Tabel 2).

Tabel 2 Hasil Pendugaan Parameter Model Terhadap Produk Domestik Regional Bruto $(\mathrm{Yt})$

\begin{tabular}{|l|c|c|}
\hline \multicolumn{1}{|c|}{ Variabel } & Koefisien & Prob \\
\hline C & -13522202 & 0,1763 \\
\hline CPFT (Kapasitas Fiskal) & $-6,673510$ & 0,0597 \\
\hline TEXPT (Pengeluaran Pemerintah Daerah) & $-0,345533$ & 0,5234 \\
\hline PMAT (Penanaman Modal Asing) & 4,750660 & 0,0378 \\
\hline PMDNT (Penanaman Modal Dalam Negeri) & 0,305591 & 0,2114 \\
\hline PENDT (Penduduk) & $3,849.889$ & 0,0001 \\
\hline R-squared & \multicolumn{2}{|c|}{0,999223} \\
Adjusted R-squared & \multicolumn{2}{|c|}{0,998251} \\
S.E. of regression & 1986529
\end{tabular}


ANALISIS PENGARUH DESENTRALISASI FISKAL, INVESTASI DAN PENDUDUK TERHADAP PRODUK DOMESTIK REGIONAL BRUTO, KAPASITAS FISKAL DAN PENGELUARAN PEMERINTAH DAERAH DI PROVINSI PAPUA

F-statistic

$\operatorname{Prob}($ F-statistic)

1028,399

J-statistic

0,000003

Sumber : diolah, 2018

0,000000

Berdasarkan tabel 2 didapat nilai kontstanta dan koefisien regresi, sehingga dapat dibentuk persamaan regresi linier berganda sebagai berikut:

$$
\begin{gathered}
\text { Yt }=-13522202-6,673510 \mathrm{CPFt}-0,345533 \text { TEXPt }+4,750660 \\
\text { PMAt }+0,305591 \text { PMDNt }+38,49889 \text { PENDt }+e
\end{gathered}
$$

Berdasarkan hasil estimasi terhadap model Produk Domestik Regional Bruto terlihat bahwa variabel kapasitas fiskal (CPFt) memiliki nilai elastisitas sebesar -6,67 yang berarti bahwa setiap kenaikan 1 persen pada kapasitas fiskal (CPFt) akan mengurangi PDRB sebesar 6,67 persen. Pengeluaran Pemerintah (TEXPt) memiliki nilai elastisitas sebesar $-0,345$ yang berarti bahwa setiap kenaikan 1 persen pada Pengeluaran Pemerintah (TEXPt) maka akan mengurangi PDRB sebesar $-0,345$ hal ini tidak sejalan dengan teori.

Secara konseptual dengan adanya belanja daerah yang berkualitas, maka akan berdampak pada nilai PDRB. Artinya secara tidak langsung seharusnya setiap pengeluaran pemerintah melalui kebijakan fiskal papua akan meningkatkan perekonomian papua yang dicerminkan melalui peningkatan nilai PDRB.

Variabel investasi yang terdiri dari PMA dan PMDN signifikan dan berpengaruh positif terhadap PDRB provinsi Papua dengan nilai elastisitas 4,75 dan 0,305. Hal ini bermakna bahwa setiap kenaikan PMA sebesar 1 persen maka akan menyebabkan PDRB naik 4,75 persen begitupun dengan kenaikan PMDN sebesar 1 persen maka PDRB naik 0,305 persen. Fakta ini sesuai dengan teori ekonomi Keynes yang menyebutkan bahwa investasi meningkatkan output total (agregat expenditure). 
Berdasarkan hasil pendugaan diketahui variabel penduduk (PEND) meningkatkan PDRB provinsi Papua dengan nilai koefisien 38,49 yang berarti bahwa setiap kenaikan penduduk 1 persen akan mampu menaikkan PDRB sebesar 38,49 persen. Variabel penduduk di provinsi Papua pada penelitiannya ini memberikan kontribusi yang sangat besar terhadap PDRB. Berdasarkan teori penduduk sangat menentukan perekonomian suatu daerah.

Hasil Estimasi Kapasitas Fiskal. Hasil estimasi model persamaan simultan terhadap kapasitas fiskal menunjukkan bahwa model yang dibangun signifikan pada taraf 5 persen dan mampu menjelaskan permasalahan dengan sangat baik. Hal ini terlihat dari nilai $R$-squared nya yaitu sebesar 0,9136 yang berarti bahwa model telah mampu menjelaskan keragaman masalah sebesar 91,36 persen dan sisanya 8,64 persen dijelaskan oleh variabel-variabel diluar model.

Tabel 3 Hasil Pendugaan Parameter Model Kapasitas Fiskal

\begin{tabular}{|l|c|c|}
\hline \multicolumn{1}{|c|}{ Variabel } & Koefisien & Prob \\
\hline C & 2241103 & 0,0435 \\
\hline YT (PDRB) & 0,005365 & 0,6000 \\
\hline RTAXT (Pajak Daerah) & $1,493.697$ & 0,0367 \\
\hline RRETT (Retribusi Daerah) & $-2,442676$ & 0,5318 \\
\hline R-squared & \multicolumn{2}{|c|}{0,913637} \\
Adjusted R-squared & \multicolumn{2}{|c|}{0,870455} \\
S.E. of regression & \multicolumn{2}{|c|}{9939759} \\
F-statistic & 2,115803 \\
Prob(F-statistic) & \multicolumn{2}{|c|}{0,001363} \\
J-statistic & \multicolumn{2}{|c|}{0,000000} \\
\hline
\end{tabular}

Sumber : diolah, 2018

Berdasarkan tabel di atas didapat nilai kontstanta dan koefisien regresi, sehingga dapat dibentuk persamaan regresi linier berganda sebagai berikut: 


$$
\text { CPFt }=2241103+0.005365 \text { Yt +14.93697 RTAXt }-24.42676 \text { RRETt }+e
$$

Variabel PDRB (Yt) dalam hasil estimasi adalah positif sebesar 0,005 namun terbukti tidak signifikan. Dengan arti lain PDRB (Yt) tidak memiliki pengaruh yang nyata terhadap kapasitas fiskal daerah. Dari hasil tersebut PDRB tidak sesuai dengan dengan hipotesis penelitian. Tetapi sesuai dengan hasil penelitian yang dilakukan oleh (Joko Tri Haryanto 2006). Pertumbuhan ekonomi dapat mengetahui kegiatan ekonomi yang dilakukan masyarakat di dalam meningkatkan produksi barang dan jasa. Pertumbuhan ekonomi meningkat, dikarenakan kegiatan ekonomi dalam memproduksi barang dan jasa meningkat.

Tanda parameter untuk Pajak Daerah adalah positif yaitu 14,936 yang menunjukkan bahwa apabila Pajak Daerah naik 1 persen maka Kapasitas Fiskal akan naik sebesar 14,936 persen, hasil regresi dengan asumsi variabel yang lain tetap (cateris paribus). Sehingga dapat disimpulkan bahwa Pajak Daerah sesuai dengan hipotesis penelitian serta sesuai dengan hasil penelitian yang dilakukan oleh Joko Tri Haryanto (2006).

Variabel Retribusi Daerah dari hasil estimasi bernilai negative sebesar 24,426 dan terbukti tidak signifikan terhadap kapasitas fiskal. Berarti terjadi penyimpangan dari hipotesis penelitian. Tetapi sesuai dengan hasil penelitian yang dilakukan oleh Joko Tri Haryanto (2006). Hal ini terjadi karena dilihat dari data retribusi daerah kurang konstan. Kontribusi retribusi daerah di provinsi Papua belum maksimal, terkadang ada aset yang harus diwajibkan membayar tetapi tidak dipungut atau terlewatkan sehingga realisasi yang diterima tidak sesuai dengan target.

Hasil Estimasi Pengeluaran Pemerintah Daerah. Hasil dari model Pengeluaran Pemerintah Daerah memperoleh nilai koefisien Adjusted $R$ squared sebesar 0.534616 atau $53.43 \%$ menunjukkan bahwa Produk Domestik Regional Bruto (Yt), kapasitas fiskal (CPFt), pendapatan asli daerah (PADt), dana perimbangan (DPt), dan penduduk (PENDt) 
memberikan pengaruh sebesar $53.43 \%$ terhadap pengeluaran pemerintah (TEXPt). Sedangkan sisanya sebesar $46.57 \%$ dipengaruhi oleh variabel lain yang tidak diamati di dalam penelitian ini.

Tabel 4 Hasil Pendugaan Parameter Model Pengeluaran Pemerintah Daerah

\begin{tabular}{|l|c|c|}
\hline \multicolumn{1}{|c|}{ Variabel } & Koefisien & Prob \\
\hline C & 9541252 & 0,6641 \\
\hline YT (PDRB) & 0,230375 & 0,5653 \\
\hline CPFT (Kapasitas Fiskal) & 0,631645 & 0,6681 \\
\hline PADT (Pajak Asli Daerah) & $1,434.582$ & 0,9133 \\
\hline DPT (Dana Perimbangan) & $-0,183401$ & 0,9480 \\
\hline PENDT (Penduduk) & $-1,142097$ & 0,5707 \\
\hline R-squared & \multicolumn{2}{|c|}{0,793163} \\
Adjusted R-squared & \multicolumn{2}{|c|}{0,534616} \\
S.E. of regression & 2360912 \\
F-statistic & \multicolumn{2}{|c|}{3,067777} \\
Prob(F-statistic) & \multicolumn{2}{|c|}{0,150002} \\
J-statistic & $1,38 \mathrm{E}-37$ \\
\hline
\end{tabular}

Berdasarkan tabel di atas didapat nilai kontstanta dan koefisien regresi, sehingga dapat dibentuk persamaan regresi linier berganda sebagai berikut:

\section{TEXPt $=9541252+0,230375 \mathrm{Yt}+0,631645 \mathrm{CPFt}+1,434582$ PADt - 0,183401 DPt - 11,42097 PEND $t+e$}

Dari model tersebut diatas diartikan bahwa variabel PDRB (Yt) berpengaruh positif meningkatkan pengeluaran pemerintah (TEXPt) daerah provinsi Papua namun pengaruhnya tidak signifikan pada taraf nyata 5 persen. Nilai estimasi positif sebesar 0,230 terhadap pengeluaran pemerintah. Hal ini karena dampak dari meningkatnya PDRB tidak langsung membuat pengeluaran pemerintah meningkat.

\section{KESIMPULAN}

Kapasitas Fiskal, Pengeluaran Pemerintah Daerah, Penanaman Modal Asing, Penanaman Modal Dalam Negeri, dan Penduduk secara 
simultan berpengaruh signifikan terhadap Produk Domestik Regional Bruto dengan total pengaruh sebesar 99,92 persen, sedangkan sisanya sebesar 0,08 persen dipengaruhi oleh variabel lain yang tidak diamati di dalam penelitian ini.

Produk Domestik Regional Bruto, Pajak Daerah, dan Retribusi Daerah secara simultan berpengaruh signifikan terhadap Kapasitas Fiskal dengan total pengaruh sebesar 91,36 persen, sedangkan sisanya sebesar 8,64 persen dipengaruhi oleh variabel lain yang tidak diamati di dalam penelitian ini.

Produk Domestik Regional Bruto, Kapasitas Fiskal, Pendapatan Asli Daerah, Dana Perimbangan, dan Penduduk secara simultan tidak berpengaruh signifikan terhadap Pengeluaran Pemerintah Daerah dengan total pengaruh sebesar 53,43 persen, sedangkan sisanya sebesar 46,57 persen dipengaruhi oleh variabel lain yang tidak diamati di dalam penelitian ini.

\section{DAFTAR PUSTAKA}

Alam, S. 2007. Ekonom, Jilid 2. Jakarta:Esis

Andayani, Sri. (2014). Analisis Pengaruh Desentralisasi Fiskal Terhadap Kualitas Pemerintahan Dan Kinerja Ekonomi DI Daerah Kabupaten/ Kota Provinsi Jawa Timur. Univesitas Brawijaya.

Abdul Halim, (2001), Bunga Rampai Manajemen Keuangan Daerah, Yogyakarta, UPP AMP YKPN.

Boediono. 1985. Pengantar ilmu ekonomi No. 4. Yogyakarta: BPFE.

Badan Pusat Statistik Republik Indonesia (2007)

Darwanto dan Yulia Yustikasari, 2007. Pengaruh Pertumbuhan Ekonomi Pendapatan Asli Daerah dan Dana Alokasi Umum terhadap Pengalokasian Anggaran Belanja Modal, Simposium Nasional Akuntansi X. Makasar.

Didir M.P. Pontjowinoto. (1991). Alternatif Reformasi Kebijakan dan Manajemen Keuangan Daerah. Prisma, Vol. XX, No. 8, hal 31-42.

Edy Suandi Hamid, (2006), Ekonomi Indonesia dari Sentralisasi ke

Desentralisasi, Yogyakarta,UII Press.

Elia Radianto. (1997). Otonomi Keuangan Daerah Tingkat II Suatu Studi di Maluku. Prisma, nomor 3, 1997, hal 39-50.

FX. Sugiyanto. (2000). Kemandirian dan Otonomi Daerah. Media Ekonomi dan Bisnis. Vol. XII, No. I, hal 1-7. 
Halim, A. dan Damayanti, T. W. (2007). Bunga Rampai Manajemen Keuangan DDaerah. UPP AMP YKPN, Jogjakarta.

Hamid, E. S. (2003). "Formula Alternatif Dana Alokasi Umum". Jurnal Ekonomi dan Bisnis Indonesia, volume 18 No 3: 224-242.

Hari, Priyoadi. (2005). "Dampak Desentralisasi Fiskal Terhadap Pertumbuhan Ekonomi". Jurnal Interdisoliner Kritis UKSW (Terakreditasi).

Haris, S. (2005). Desentralisasi dan Otonomi Daerah : Desentralisasi, Demokratisasi dan Akuntabilitas Pemerintahan Daerah. LIPI Press, Jakarta.

Herman, Asaribab. (2014). Laporan Studi Strategis Dalam Negri Peserta PPRA LII LEMHANMAS RI tentang Pembangunan Nasioan Provinsi Papua, Jakarta, Lembaga Ketahanan Nasional Republik Indonesia.

Jatmoko, Ahmad. (2005). Analisis Pengaruh PAD Terhadap PDRB di Provinsi Jawa Barat.

Jonathan, Sarwono. (2006). Metode Penelitian Kuantitatif dan Kualitatif. Yogyakarta :Graha Ilmu

Joko, Tri Haryanto. (2006). "Kemandirian Daerah : Sebuah Perspektif dengan Metode Path Analisys", Jurnal Manajemen Usahawan, Nomor 03 Th XXXV Maret 2006, Lembaga Management FE-UI, Jakarta, hal. 45.

Julitawati, dkk. (2012). Pengaruh Pendapatan Asli Daerah (PAD) dan Dana Perimbangan Terhadap Kinerja Keuangan Pemerintah Kabupaten/Kota di Provinsi Aceh. Jurnal Akuntansi. Universitas Syiah Kuala

Kaho, Joseph Riwu, (1998), Prospek Otonomi Daerah di Negara Republik Indonesia, Jakarta, Raja Grafindo Persada.

Kaho, Josef Riwu, (1997), Prospek Ekonomi di Negara Republik Indonesia Fak.Sospol-UGM, Yogyakarta

Kaloh, J. (2002). Mencari Bentuk Otonomi Daerah, Jakarta : PT. Rineka Cipta.

Khalid, Idham. (2015). Pengaruh Desentralisasi Fiskal Terhadap Pertumbuhan Ekonomi Di Sulawesi Selatan, Sulawesi Selatan : Universitas Muhammadiyah Makasar.

Ladjin, Nurjanna. (2008). Analisis Kemandirian Fiskal Di Era Otonomi Daerah (Studi Kasus Di Propinsi Sulawesi Tengah). Semarang: Universitas Diponegoro.

Mardiasmo. (1999). Pengelolaan Keuangan Daerah yang Berorientasi pada Kepentingan Publik. PAU Studi Ekonomi UGM. Yogyakarta. . (2002). Otonomi dan Manajemen Keuangan Daerah. Yogyakarta, Penerbit Andi.

Muin, Fatkhul. 2014. "Otonomi Daerah Dalam Persepektif Pembagian Urusan Pemerintahan-Pemerintahan Daerah Dan Keuangan Daerah". Fiat Justisia Jurnal IImu Hukum Volume 8 No. 1, JanuariMaret. Univesitas Sultan Ageng Tirtayasa. 
Munir Dasril, H. A. Djuanda dan H. N. Tangkilisan (2004), Kebijakan dan Manajemen Keuangan Daerah, Yogyakarta, Penerbit YPAPI.

Nurlan Darise. (2009). Pengelolaan Keuangan Daerah Pedoman untuk Eksekutifdan Legislatif. Jakarta: Indeks.

Pambudi, Septian B. (2008). Analisis Pengaruh Tingkat Kemandirian Fiskal Terhadap Indeks Pembangunan Manusia Kabupaten/Kota Di Provinsi Jawa Barat. Bogor: Institut Pertanian Bogor.

Permendagri No. 13 Tahun 2006 tentang Pedoman Pengelolaan Keuangan Daerah

Permenkeu No. 245 Tahun 2006 tentang Peta Kapasitas Fiskal Daerah.

Permenkeu No. 37 Tahun 2016 tentang Peta Kapasitas Fiskal Daerah.

Republik Indonesia , (2004-a), Undang-Undang Nomor 32 Tahun 2004 tentang Pemerintah Daerah.

Republik Indonesia , (2004-b), Undang-Undang Nomor 33 Tahun 2004 tentang Perimbangan Keuangan Antara Pemerintah Pusat dan Pemerintah Daerah.

Riduwan \& Sunarto. (2010). Pengantar Statistika Untuk Penelitian: Pendidikan, Sosial, Komunikasi, Ekonomi, dan Bisnis. Bandung: Alfabeta.

Sadono Sukirno, (2004), Pengantar Teori Makroekonomi, Jakarta: Raja grafindo Persada

Sarsiti dan Rakiman,2011. Jurnal "pengaruh Pendapatan Perkapita dan jumlah wajib pajak terhadap penerimaan pajak penghasilan di kabupaten sukoharjo periode 2002-2010.

Sasana. Hadi 2009. "Peran Desentralisasi Fiskal Tehadap Kinerja Ekonomi di Kabupaten/Kota Provinsi Jawa Tengah". Jurnal Ekonomi Pembangunan Vol 10, No.1, Juni 2009

Sidik, M., R. Simanjuntak, B. Brodjonegoro. (2002). Dana Alokasi Umum : Konsep, Hambatan dan Prospek Di Era Otonomi Daerah. Penerbit Buku Kompas, Jakarta.

Siregar, S. (2010). Statistika Deskriptif Untuk Penelitian: Dilengkapi perhitungan Manual dan Aplikasi SPSS Versi 17. Jakarta: Rajawali Pers.

Sudjana, D (2001), Metode \& Teknik pembelajaran partisipatif. Bandung: Falah Production

Sukanto Reksohadiprodjo, (2001), Ekonomi Publik, Yogyakarta, BPFE UGM.

Sukirno, Sadono. (2004). Makro Ekonomi Teori Pengantar. Edisi-3. PT. Raja Grafindo. Persada, Jakarta.

Sumitro Djojohadikusumo, (1994), Dasar Teori Ekonomi Pertumbuhan dan Ekonomi Pembangunan, Jakarta, LP3ES.

Sumarsono, Hadi dan Utomo, Sugeng Hadi, 2009. "Deliberate Inflation pada Kebijakan Desentralisasi Fiskal Jawa Timur dan Dampaknya bagi Pertumbuhan Daerah": Jurnal Ekonomi Studi Pembangunan, JESP Vol. 1, No. 3, 2009 
Suprajitno, Pudji. (2003). Analisis Faktor-Faktor Yang Mempengaruhi Kemandirian Fiskal Daerah (Studi Kasus di Kabupaten Banjarnegara). Semarang: Universitas Diponegoro.

Supraktiko, Joko, dkk. (2017). Kajian Ekonomi dan Keuangan Regional Provinsi Papua, Papua, Bank Indonesia Provinsi Papua.

Suseno Triyanto Widodo, (1990), Indikator Ekonomi : Dasar Perhitungan Perekonomian Indonesia, Yogyakarta, Penerbit Kanisius.

Triani, Mike. (2015). Analisis Kebijakan Otonomi Daerah Terhadap Pertumbuhan Ekonomi Di Sumatra Barat Dalam Menghadapi Masyarakat Ekonomi Asean. Universitas Negeri Padang.

Tulus TH Tambunan,. (2003), Perekonomian Indonesia : Beberapa Masalah Penting, Jakarta, Ghalia Indonesia.

Turtiantoro. (2000). Otonomi Daerah Dalam Prespektif Administrasi Pembangunan. Media Ekonomi dan Bisnis. Vol. XII, No. I, hal 2531.

Untoro, Joko, 2010, Ekonomi, Jakarta, Kawahmedia

Undang-Undang Republik Indonesia Nomor 28 Tahun 2009 Pajak Daerah

Yuliati, 2001, Analisis Kemampuan Keuangan Daerah Dalam Menghadapi Otonomi Daerah, Bunga Rampai Manajemen Keuangan Daerah, UPP AMP YKPN, Yogyakarta.

Yuniarti, Ari. (2008). Pengaruh Pertumbuhan Pendapatan Perkapita, Tingkat Investasi Dan Tingkat Industrialisasi Terhadap Kemandirian Daerah Studi Kasus: Kabupaten dan Kota Di Wilayah Soloraya). Surakarta : Universitas Sebelas Maret.

Zhang Tao dan Zou Heng fu. (1998). "Fiscal Decentralization. Public Spending and Economic Growth in China", Journal of Public Expenditure 67,221240.)

Internet:

Fauzan. "Pertumbuhan ekonomi di Papua triwulan II alami peningkatan". 26 Desember 2017.

https://elshinta.com/news/122050/2017/09/28/pertumbuhan-ekonomidi-papua-triwulan-ii-alami-peningkatan 